\title{
Synthesis, Sigma Receptor Binding Studies, and In Vivo Evaluation of Radioiodinated (Z)- and (E)-iodoallyl Analogs of SA4503
}

\author{
Rong $\mathrm{Xu}^{1}$, Lisa D. Watkinson ${ }^{2,5}$, Terry L. Carmack ${ }^{2,5}$, John R. Lever ${ }^{2,3,5}$ and Susan Z. Lever ${ }^{1,4 *}$ \\ ${ }^{1}$ Department of Chemistry, University of Missouri, Columbia, MO 65211 USA \\ ${ }^{2}$ Department of Radiology, University of Missouri, Columbia, MO 65212 USA \\ ${ }^{3}$ Department of Medical Pharmacology and Physiology, University of Missouri, Columbia, MO 65212 USA \\ ${ }^{4}$ University of Missouri Research Reactor Center, University of Missouri, Columbia, MO 65211 USA \\ ${ }^{5}$ Harry S. Truman Memorial Veterans' Hospital, Columbia, MO 65201 USA
}

\begin{abstract}
SA4503, a potent $\sigma_{1}$ receptor agonist, is under study for functional recovery after stroke, and has been tested for treatment of major depression. Recent behavioral studies indicate that SA4503 can also display antagonist properties, and attenuates psychostimulant-induced hyperactivity in animal models. Further, SA4503 labeled with carbon-11 (halflife $20.4 \mathrm{~min}$ ), or analogs labeled with fluorine-18 (half-life $109.7 \mathrm{~min}$ ), are useful for PET studies of the $\sigma_{1}$ receptor. Analogs labeled with iodine-123 (13.2 h half-life) would have potential as SPECT imaging agents, while analogs labeled with iodine-125 (60.1 d half-life) could be used routinely in laboratory studies. Toward these ends, we describe the synthesis and radiolabeling, as well as in vitro and in vivo binding studies, of two SA4503 analogs where the 4-methoxy group of the dimethoxyphenethyl moiety is replaced by either a (Z)- or (E)-iodoallyloxy substituent. The iodoallyl groups were introduced by base-promoted coupling of stannylated alkylating agents to 4-O-des-methyl-SA4503, followed by iododestannylation with retention of configuration. Both $(Z)$ - and $(E)$-iodoallyl-SA4503 displayed moderately high affinities for $\sigma_{1}$ and $\sigma_{2}$ receptors in vitro $\left(K_{\mathrm{i}}\right.$ values 11-18 $\left.\mathrm{nM}\right)$. The corresponding radioiodinated ligands were prepared in good yields $(57-58 \%)$, with high purities $(>97 \%)$ and high specific activities $(>2000 \mathrm{mCi} / \mu \mathrm{mol})$. Both radioligands readily crossed the blood-brain-barrier of mice, although their $\log D_{7.4}$ values of 3.6 were relatively high. Haloperidol pretreatment defined a modest degree of specific binding to $\sigma_{1}$ receptors, but only for the $\left[{ }^{125}\right]$-labeled $(E)$-isomer in mouse brain (28\%) and liver (25\%) at 60 min. Thus, these particular radioligands are not well suited to in vivo studies. More significantly, the work shows that $\sigma$ receptors display substantial tolerance to bulky structural modifications of SA4503, a feature that might aid in the future development of possible therapeutics based on the SA4503 scaffold.
\end{abstract}

Keywords: Sigma receptor; SA4503; Structure activity relationship; Radioiodine; Lipophilicity

\begin{abstract}
Abbreviations: SPECT: Single Photon Emission Computed Tomography; PET: Positron Emission Tomography; HPLC: High Performance Liquid Chromatography; $t_{\mathrm{R}}$ : Retention Time; HRMSESI: High Resolution Mass Spectrometry - Electrospray Ionization; NMR: Nuclear Magnetic Resonance; Tris-HCl: Tris(Hydroxymethyl) Aminomethane Hydrochloride; DMF: Dimethylformamide; \%ID: Percent Injected Dose; SD: Standard Deviation; SEM: Standard Error of the Mean; SA4503: 1-(3,4-dimethoxyphenethyl)-4-(3-phenylpropyl) piperazine; o-BON: 1-[2-(3,4-Dimethoxyphenyl)ethyl]-4-[3-(2iodophenyl)propyl]piperazine; $m$-BON: 1-[2-(3,4-Dimethoxyphenyl) ethyl]-4-[3-(3-iodophenyl)propyl]piperazine
\end{abstract}

\section{Introduction}

SA4503 (Figure 1) has potent sigma $\left(\sigma_{1}\right)$ receptor agonist properties [1], and is under study in Phase II clinical trials for functional recovery after stroke [2]. SA4503 also has been tested for treatment of major depressive disorder (ClinicalTrials.gov Identifier: NCT00551109). Recent behavioral studies indicate that SA4503 can also display antagonist properties, and attenuates cocaine- and methamphetamineinduced hyperactivity in animal models [3,4]. Thus, SA4503 may be best described as a mixed agonist-antagonist. SA4503 has been labeled with carbon-11 (half-life $20.4 \mathrm{~min}$ ), and used successfully for PET studies of the $\sigma_{1}$ receptor in human beings [5-7]. The fluoroethyl analog, FE-SA4503 (Figure 1), has been labeled with fluorine-18 (halflife $109.7 \mathrm{~min}$ ) and also allows PET visualization of the $\sigma_{1}$ receptor in conscious monkey brain $[8,9]$.

Our interest in the development of probes for $\sigma$ receptors [10-14] has prompted us to investigate a pair of novel iodoallyl (IA) analogs of SA4503, (Z)- and (E)-IA-SA4503, that can readily incorporate radioiodine (Figure 1; 1, 2). $\left.{ }^{[25} \mathrm{I}\right]$-Labeled receptor ligands (60.1 d halflife) have high specific activity $(2175 \mathrm{mCi} / \mu \mathrm{mol})$, are easy to detect without tissue processing, and can be used routinely for laboratory studies. Further, $\left.{ }^{[23} \mathrm{I}\right]$-labeled ligands $(13.2 \mathrm{~h}$ half-life $)$ have the potential for use as SPECT imaging agents in nuclear medicine clinics, and offer some advantages over PET ligands labeled with short halflife radionuclides such as carbon-11 and fluorine-18. SA4503 analogs radioiodinated at the aromatic ring of the 3-phenylpropyl moiety, $o$ and $m$-BON (Figure 1), have been reported by others $[15,16]$. Here we describe the synthesis and radiolabeling, as well as in vitro and in vivo studies, of complementary SA4503 analogs where radioiodine is incorporated through $(Z)$ - or $(E)$-iodoallyloxy substituents at the 4-position of the dimethoxyphenethyl moiety.

\section{Materials and Methods}

\section{General information}

Chemicals and solvents were reagent grade, and used as received from commercial sources. Literature procedures were used to

*Corresponding author: Susan Z. Lever, PhD, Room 125 Chemistry Building University of Missouri, 601 South College Avenue, Columbia, MO 65211 USA, Tel: (573) 882-8395; Fax: (573) 882-2754; E-mail: levers@missouri.edu

Received July 30, 2012; Accepted October 10, 2012; Published October 12 2012

Citation: Xu R, Watkinson LD, Carmack TL, Lever JR, Lever SZ (2012) Synthesis Sigma Receptor Binding Studies, and In Vivo Evaluation of Radioiodinated (Z)and $(E)$-iodoallyl Analogs of SA4503. Med chem 2:131-136. doi:10.4172/21610444.1000128

Copyright: (c 2012 Xu R, et al. This is an open-access article distributed under the terms of the Creative Commons Attribution License, which permits unrestricted use, distribution, and reproduction in any medium, provided the original author and source are credited. 

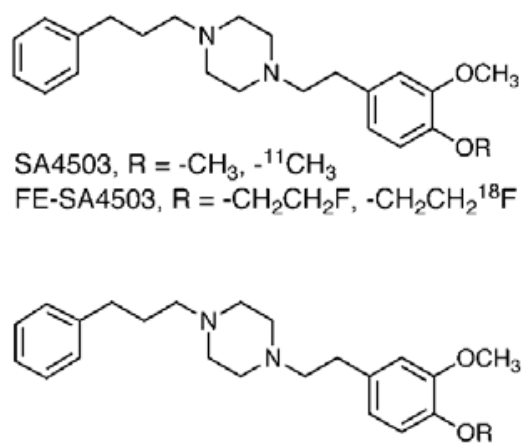

1: (Z)-|A-SA4503, $\mathrm{R}=(Z)-\mathrm{CH}_{2} \mathrm{CH}=\mathrm{CHI} ;{ }^{127} \mid$ and ${ }^{125} \mid$ 2: (E)-IA-SA4503, $\mathrm{R}=(E)-\mathrm{CH}_{2} \mathrm{CH}=\mathrm{CHI} ;{ }^{127}$ I and ${ }^{125} \mathrm{I}$

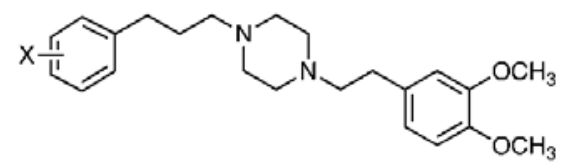

o-BON, $X=0-1,{ }^{127} \mid$ and ${ }^{125}$ $m$-BON, $X=m-1,{ }^{127} \mid$ and ${ }^{125} \mid$

Figure 1: Structures of SA4503, FE-SA4503, novel (Z)- and (E)-iodoallyl analogs of SA4503, o-BON and $m-B O N$.

prepare 4-O-des-methyl-SA4503 [8], as well as (Z)- and (E)-3-(tri- $n$ butylstannyl)prop-2-en-1-ol 4-methylbenzenesulfonate [17]. ${ }^{1} \mathrm{H}$ NMR spectra were obtained on Bruker ARX-250 (250 MHz) or DRX-300 $(300 \mathrm{MHz})$ spectrometers. ${ }^{13} \mathrm{C}$ NMR spectra were obtained on Bruker ARX-250 (62.5 MHz) or DRX-300 (75 MHz) spectrometers. Chemical shifts $\left({ }^{1} \mathrm{H}\right)$ are reported in ppm $(\delta)$ relative to internal tetramethylsilane in $\mathrm{CDCl}_{3}$, or to the central peak of $\mathrm{CDCl}_{3}\left({ }^{13} \mathrm{C}\right)$. HRMS-ESI analyses were obtained using a TSQ7000 mass spectrometer (Thermo Finnigan, San Jose, CA). Compounds 1 and 2 were converted to di$\mathrm{HCl}$ salts for storage and ease of handling. Elemental analyses were determined by Atlantic Microlab, Inc., Norcross GA. Column Column chromatography was performed under $\mathrm{N}_{2}$ pressure using $230-400$ mesh Silicycle ${ }^{\circledR}$ UltraPure silica gel.

No-carrier-added $\left[{ }^{125} \mathrm{I}\right] \mathrm{NaI}$, as well as $\left[{ }^{3} \mathrm{H}\right] \mathrm{DTG}$ and $\left[{ }^{3} \mathrm{H}\right]$ (+)-pentazocine, were obtained from PerkinElmer, Inc. (Waltham, MA). A Brandel R48 manifold (Brandel Instruments, Gaithersburg, MD) was used for rapid filtrations of receptor binding assays. Tritium radioactivity was measured using a Wallac 1409 liquid scintillation counter and OptiPhase ${ }^{\circledR}$ HiSafe 2 cocktail at $44 \%$ efficiency. Radioiodine was measured during synthetic procedures with a dose calibrator (Capintec CRC-15W). Analytical radioiodine counting was performed with a Wallac (Turku, Finland) Wizard ${ }^{\circledR} 1480$ automated gamma counter at $78 \%$ efficiency. A Waters (Milford, MA) C-18 Nova$\mathrm{Pak}^{\circledR}$ radial compression module column $(8 \times 100 \mathrm{~mm}, 4 \mu \mathrm{m})$ was used for semi-preparative HPLC, and a Waters C-18 Nova-Pak ${ }^{\circledR}$ stainless steel column $(3.9 \times 150 \mathrm{~mm}, 4 \mu \mathrm{m})$ was used for analytical HPLC. Solid-phase extraction cartridges (Waters Sep-Pak ${ }^{\circledR}$ Light $t$-C-18) were activated prior to use by sequential elution with $\mathrm{EtOH}$ and $\mathrm{H}_{2} \mathrm{O}$.

Frozen Hartley guinea pig brains were obtained from Rockland Immunochemicals, Inc. (Gilbertsville, PA). Male CD1 mice were obtained from Charles River Laboratories International, Inc. (Wilmington, MA). All studies involving living animals were performed humanely in compliance with National Institutes of Health guidelines, and with prior approvals from the Institutional Animal Care and Use
Committees of the University of Missouri and the Harry S. Truman Memorial Veterans' Hospital.

\section{Chemistry}

(Z)-1-(3-methoxy-4-(3-(tri- $n$-butylstannyl)allyloxy)phenethyl)4-(3-phenylpropyl)piperazine (4): $\mathrm{NaH}$ (6.3 g, $0.26 \mathrm{~mol}$ ) was added to a stirred solution of 4 -O-des-methyl-SA4503.2 $\mathrm{HCl}(7.0 \mathrm{~g}, 0.016 \mathrm{~mol})$ in $300 \mathrm{~mL} \mathrm{DMF}$ under $\mathrm{N}_{2}$ at room temperature. After $1 \mathrm{~min}$, a solution of (Z)-3-(tri-n-butylstannyl)prop-2-en-1-ol 4-methylbenzenesulfonate $(30.0 \mathrm{~g}, 0.06 \mathrm{~mol})$ in $80 \mathrm{~mL}$ DMF was added. After $90 \mathrm{~min}$, the reaction was quenched by slow addition of saturated $\mathrm{NH}_{4} \mathrm{Cl}$ and extracted with $\mathrm{CH}_{2} \mathrm{Cl}_{2}$. The extracts were washed with saturated $\mathrm{NaHCO}_{3}$ and concentrated under reduced pressure. Column chromatography $\left(\mathrm{CHCl}_{3}: \mathrm{MeOH}, 20: 1\right)$ gave $4(7.69 \mathrm{~g}, 70 \%)$ as a yellow oil. ${ }^{1} \mathrm{H}$ NMR: $\left(\mathrm{CDCl}_{3}\right)$ 0.85-0.96 (m, 15H, $\left.n-\mathrm{Bu}\right), 1.27-1.46(\mathrm{~m}, 12 \mathrm{H}, n-\mathrm{Bu}), 1.79$ $1.95\left(\mathrm{~m}, 2 \mathrm{H}, \mathrm{CH}_{2}\right), 2.56-2.63\left(\mathrm{~m}, 16 \mathrm{H}, \mathrm{CH}_{2}\right), 3.84\left(\mathrm{~s}, 3 \mathrm{H}, \mathrm{CH}_{3}\right), 4.49$ $4.51\left(\mathrm{dd}, 2 \mathrm{H}, \mathrm{CH}_{2}, J=1.1,5.9 \mathrm{~Hz}\right), 6.17-6.22(\mathrm{dt}, 1 \mathrm{H}, \mathrm{CH}, J=1.1,13.1$ $\mathrm{Hz}), 6.68-6.82(\mathrm{~m}, 4 \mathrm{H}$, alkene $\mathrm{CH}$, aromatic $\mathrm{CH}), 7.17-7.29(\mathrm{~m}, 5 \mathrm{H}$, aromatic $\mathrm{CH})$.

(Z) - 1-(4-(3-iodoallyloxy)-3-methoxyphenethyl)-4-(3phenylpropyl)piperazine (1): A solution of $4(2.0 \mathrm{~g}, 2.99 \mathrm{mmol})$ in 40 $\mathrm{mL} \mathrm{CH} \mathrm{Cl}_{2}$ was added to $\mathrm{I}_{2}(859 \mathrm{mg}, 3.38 \mathrm{mmol})$ in $20 \mathrm{~mL} \mathrm{CH}_{2} \mathrm{Cl}_{2}$. The reaction was stirred for $10 \mathrm{~min}$ at room temperature and quenched with an aqueous solution of $\mathrm{Na}_{2} \mathrm{~S}_{2} \mathrm{O}_{5}$. The organic layer was separated and the aqueous phase was extracted with $\mathrm{CH}_{2} \mathrm{Cl}_{2}$. The combined organic extracts were dried over anhydrous $\mathrm{Na}_{2} \mathrm{SO}_{4}$, filtered and concentrated under reduced pressure. Dissolution in $\mathrm{EtOH}$ followed by precipitation with $\mathrm{HCl}$ gave 1 as the di- $\mathrm{HCl}$ salt $(0.98 \mathrm{~g}, 55 \%$ yield $)$. ${ }^{1} \mathrm{H}$ NMR: $\left(\mathrm{CDCl}_{3}\right)$ 1.81-1.90 (m, 2H, $\left.\mathrm{CH}_{2}\right), 2.37-2.85\left(\mathrm{~m}, 16 \mathrm{H}, \mathrm{CH}_{2}\right)$, 3.87 (s, $\left.3 \mathrm{H}, \mathrm{OCH}_{3}\right), 4.66-4.68$ (dd, $\left.2 \mathrm{H}, \mathrm{CH}_{2}, J=1.8,5.2 \mathrm{~Hz}\right), 6.43-6.47$ $(\mathrm{dt}, 1 \mathrm{H}, J=7.9,1.8 \mathrm{~Hz}, \mathrm{CH}), 6.59-6.66(\mathrm{dt}, 1 \mathrm{H}, J=7.9,5.2 \mathrm{~Hz}, \mathrm{CH}), 6.71-$ $6.80(\mathrm{~m}, 3 \mathrm{H}), 7.15-7.31(\mathrm{~m}, 5 \mathrm{H}) .{ }^{13} \mathrm{C}$ NMR: $\left(\mathrm{CDCl}_{3}\right) 28.56,33.19,33.68$, $53.17,55.83,57.98,60.55,71.95,83.09,112.43,113.66,120.49,125.69$, $128.24,128.32,133.88,137.60,142.07,145.76,149.25$; HRMS-ESI: $m / z$ calcd, 520.1587; found 521.1482 [M + H] $]^{+}$; Anal. Calcd for the di-HCl salt $\left(\mathrm{C}_{25} \mathrm{H}_{35} \mathrm{Cl}_{2} \mathrm{IN}_{2} \mathrm{O}_{2}\right)$ : $\mathrm{C}, 50.60 ; \mathrm{H}, 5.95 ; \mathrm{N}, 4.72$. Found: $\mathrm{C}, 50.46 ; \mathrm{H}$ $5.92 ; \mathrm{N}, 4.65$.

(E)-1-(3-methoxy-4-(3-(tri-n-butylstannyl)allyloxy)phenethyl)4-(3-phenylpropyl)piperazine (5): $\mathrm{NaH}(4.75 \mathrm{~g}, 198 \mathrm{mmol})$ was added to a stirred solution of 4 -O-des-methyl-SA4503.2 $\mathrm{HCl}(6.35$ $\mathrm{g}, 12.4 \mathrm{mmol}$ ) in $300 \mathrm{~mL}$ DMF under $\mathrm{N}_{2}$ at room temperature. After $1 \mathrm{~min}$, a solution of (E)-3-(tri- $n$-butylstannyl)prop-2-en-1-ol 4-methylbenzenesulfonate $(12.4 \mathrm{~g}, 24.7 \mathrm{mmol})$ in $72 \mathrm{~mL}$ DMF was added. After $90 \mathrm{~min}$, the reaction was quenched by slow addition of saturated $\mathrm{NH}_{4} \mathrm{Cl}$ and extracted with $\mathrm{CH}_{2} \mathrm{Cl}_{2}$. The extracts were washed with saturated $\mathrm{NaHCO}_{3}$ and concentrated under reduced pressure. Column chromatography $\left(\mathrm{CHCl}_{3}: \mathrm{MeOH}, 20: 1\right)$ gave $5(10.3 \mathrm{~g}, 80 \%)$ as a yellow oil. ${ }^{1} \mathrm{H}$ NMR: $\left(\mathrm{CDCl}_{3}\right)$ 0.86-0.93 $(\mathrm{m}, 15 \mathrm{H}, n-\mathrm{Bu}), 1.26-1.51$ (m, $12 \mathrm{H}, n-\mathrm{Bu}), 1.79-1.90\left(\mathrm{~m}, 2 \mathrm{H}, \mathrm{CH}_{2}\right), 2.57-2.68\left(\mathrm{~m}, 16 \mathrm{H}, \mathrm{CH}_{2}\right), 3.87$ (s, $\left.3 \mathrm{H}, \mathrm{CH}_{3}\right), 4.61-4.63\left(\mathrm{dd}, 2 \mathrm{H}, \mathrm{CH}_{2}, J=1,4.6 \mathrm{~Hz}\right), 5.95-6.45(\mathrm{~m}, 2 \mathrm{H}$, $\mathrm{CH}=\mathrm{CH}), 6.71-6.81(\mathrm{~m}, 3 \mathrm{H}$, aromatic $\mathrm{CH}), 7.18-7.28(\mathrm{~m}, 5 \mathrm{H}$, aromatic $\mathrm{CH}) .{ }^{13} \mathrm{C} \mathrm{NMR:}\left(\mathrm{CDCl}_{3}\right)$ 9.35, 13.60, 27.16, 29.01, 33.13, 33.63, 53.09, $55.78,57.93,60.57,72.52,112.18,113.59,120.33,125.66,128.28$, $131.83,132.96,142.00,143.04,146.34,149.11$.

(E) - 1-(4-(3-iodoallyloxy)-3-methoxyphenethyl)-4-(3phenylpropyl)piperazine (2): To a solution of $5(10.3 \mathrm{~g}, 15 \mathrm{mmol})$ in $200 \mathrm{~mL} \mathrm{CH}_{2} \mathrm{Cl}_{2}$ was added $\mathrm{I}_{2}$ (4.32 g, $17 \mathrm{mmol}$ ) in $100 \mathrm{~mL} \mathrm{CH}_{2} \mathrm{Cl}_{2}$. The reaction was stirred for $10 \mathrm{~min}$ at room temperature and quenched with an aqueous solution of $\mathrm{Na}_{2} \mathrm{~S}_{2} \mathrm{O}_{5}$. The organic layer was separated and the aqueous phase was extracted with $\mathrm{CH}_{2} \mathrm{Cl}_{2}$. The combined organic 
extracts were dried over anhydrous $\mathrm{Na}_{2} \mathrm{SO}_{4}$, filtered, and concentrated under reduced pressure. Dissolution in $\mathrm{EtOH}$ followed by precipitation with $\mathrm{HCl}$ gave 2 as the di- $\mathrm{HCl}$ salt $(5.9 \mathrm{~g}, 56 \%) .{ }^{1} \mathrm{H} \mathrm{NMR}:\left(\mathrm{CDCl}_{3}\right) 1.78$ $1.88\left(\mathrm{~m}, 2 \mathrm{H}, \mathrm{CH}_{2}\right), 2.37-2.78\left(\mathrm{~m}, 16 \mathrm{H}, \mathrm{CH}_{2}\right), 3.85\left(\mathrm{~s}, 3 \mathrm{H}, \mathrm{OCH}_{3}\right), 4.45-$ 4.47 (dd, $\left.2 \mathrm{H}, \mathrm{CH}_{2}, J=1.4,5.5 \mathrm{~Hz}\right), 6.47-6.52(\mathrm{dt}, 1 \mathrm{H}, J=1.4,14.6 \mathrm{~Hz}$, $\mathrm{CH}), 6.69-6.80(\mathrm{~m}, 4 \mathrm{H}), 7.15-7.30(\mathrm{~m}, 5 \mathrm{H}) .{ }^{13} \mathrm{C} \mathrm{NMR:}\left(\mathrm{CDCl}_{3}\right) 28.53$, $33.18,33.64,53.13,55.80,57.93,60.48,70.86,79.86,112.48,113.99$, 120.47, 125.68, 128.22, 128.30, 134.07, 140.85, 142.02, 145.65, 149.37; HRMS-ESI: $m / z$ calcd, 520.1587; found $521.1278[\mathrm{M}+\mathrm{H}]^{+}$; Anal. Calcd for the di- $\mathrm{HCl}$ salt $\left(\mathrm{C}_{25} \mathrm{H}_{35} \mathrm{Cl}_{2} \mathrm{IN}_{2} \mathrm{O}_{2}\right)$ : C, $50.60 ; \mathrm{H}, 5.95 ; \mathrm{N}, 4.72$. Found: C, $50.50 ; \mathrm{H}, 5.91 ; \mathrm{N}, 4.70$.

\section{Radioiodination}

[25I]-1: Compound $4(0.10 \mathrm{mg}, 150 \mathrm{nmol})$ in $\mathrm{MeOH}(25 \mu \mathrm{L})$ was transferred to a glass vial sealed with a Teflon-faced septum. $\left.{ }^{125} \mathrm{I}\right] \mathrm{NaI}$ (15 $\mu \mathrm{L}, 1.55 \mathrm{mCi}, 0.75 \mathrm{nmol}$ ), $75 \mu \mathrm{L} \mathrm{MeOH}$ containing 3\% HOAc, and aqueous Chloramine-T (10 $\mu \mathrm{L}, 7.0 \mathrm{mM} ; 70 \mathrm{nmol})$ were added sequentially. After $1 \mathrm{~min}$, the reaction was quenched by the addition of $\mathrm{Na}_{2} \mathrm{~S}_{2} \mathrm{O}_{5}(10 \mu \mathrm{l}, 50 \mathrm{mM})$. Semi-preparative reverse-phase HPLC (280 $\mathrm{nm}$ UV detector; flow-through radioactivity detector) was run at a flow rate of $4 \mathrm{~mL} / \mathrm{min}$ using the mobile phase $\mathrm{MeOH}(20 \%), \mathrm{CH}_{3} \mathrm{CN}(20 \%)$ and an aqueous solution $(60 \%)$ of $\mathrm{Et}_{3} \mathrm{~N}(2.1 \% v / v)$ and HOAc $(2.8 \%$ $v / v)$. The $Z$-isomer [ $\left.{ }^{125} \mathrm{I}\right]-1\left(t_{\mathrm{R}}=27.2 \mathrm{~min}\right)$ was obtained in a volume of $11 \mathrm{~mL}$. Dilution with water $(25 \mathrm{~mL})$ followed by solid-phase extraction and elution of the cartridge with EtOH $(1.0 \mathrm{~mL})$, provided $\left[{ }^{125} \mathrm{I}\right]-1$ in $58 \%$ radiochemical yield. The radiochemical purity was $97 \%$, and the specific activity was determined to be $2106 \mathrm{mCi} / \mu \mathrm{mol}$ (vide infra). Analytical HPLC, using the same detection methods and the same mobile phase at a flow rate of $2 \mathrm{~mL} / \mathrm{min}$, confirmed that [ $\left.{ }^{125} \mathrm{I}\right]-1 \mathrm{co}-$ eluted with non-radioactive $1\left(t_{\mathrm{R}}=21.2 \mathrm{~min}\right)$, and was resolved from $E$-isomer $2\left(t_{\mathrm{R}}=23.5 \mathrm{~min}\right)$ upon co-injection.

[ $\left.{ }^{125} \mathrm{I}\right]-2$ : Similar treatment of 5 with $\left[{ }^{125} \mathrm{I}\right] \mathrm{NaI}$ and Chloramine-T gave $\left[{ }^{125} \mathrm{I}\right]-2\left(t_{\mathrm{R}}=29.4 \mathrm{~min}\right)$ after semi-preparative reverse-phase HPLC under the conditions described above. Solid phase extraction provided a $57 \%$ radiochemical yield of material with high purity and specific activity $(2097 \mathrm{mCi} / \mu \mathrm{mol})$. Analytical HPLC, as described above, showed that $\left[{ }^{125} \mathrm{I}\right]-2$ co-eluted with non-radioactive $2\left(t_{\mathrm{R}}=23.5 \mathrm{~min}\right)$, and was resolved from $Z$-isomer $1\left(t_{\mathrm{R}}=21.2 \mathrm{~min}\right)$ upon co-injection.

Specific activities, radioactivity per unit mass, were established for $\left[{ }^{125} \mathrm{I}\right]-1$ and $\left[{ }^{125} \mathrm{I}\right]-2$ by using HPLC to determine the mass associated with an aliquot of purified material having known radioactivity. To increase sensitivity, analytical HPLC conditions were chosen where isomers 1 and 2 were not fully resolved, but eluted rather quickly. Using the mobile phase $\mathrm{MeOH}(22.5 \%), \mathrm{CH}_{3} \mathrm{CN}$ (22.5\%) and an aqueous solution (55\%) of $\mathrm{Et}_{3} \mathrm{~N}(2.1 \% v / v)$ and $\mathrm{HOAc}(2.8 \% v / v)$ at 2 $\mathrm{mL} / \mathrm{min}$ gave $Z$-isomer 1 with $t_{\mathrm{R}}=10.4 \mathrm{~min}$ and $E$-isomer 2 with $t_{\mathrm{R}}=11.4$ $\mathrm{min}$. Seven-point standard curves were generated for each isomer by relating HPLC peak heights for non-radioactive material over a 45-500 pmol mass range.

\section{Lipophilicity determinations}

$\log \mathrm{D}_{7.4}$ measurements for $\left[{ }^{125} \mathrm{I}\right]-1$ and $\left[{ }^{125} \mathrm{I}\right]-2$ were determined by serial partitioning $(n=6)$ of $4 \mu \mathrm{Ci}$ of each compound between equal volumes $(3.5 \mathrm{~mL})$ of $n$-octanol and Dulbecco's phosphate buffered saline (0.1 M, pH 7.4; DPBS) in $15 \mathrm{~mL}$ polypropylene centrifuge tubes as previously described [14]. Each phase was saturated with the other phase before use. Duplicate samples from each organic layer $(100 \mu \mathrm{l})$ and each aqueous buffer layer $(1.0 \mathrm{~mL})$ were counted, and distribution coefficients at $\mathrm{pH} 7.4\left(\log \mathrm{D}_{7.4}\right)$ were calculated by taking the $\log$ of [(organic counts $\times 10) /$ buffer counts]. The algorithms for calculating ClogP for non-radioactive compounds [18] were developed by
BioByte Corp. (Claremont, CA), and were included as part of program ChemBioDraw Ultra, version 12.0 (CambridgeSoft Corporation, Cambridge, MA).

\section{Receptor binding}

Assays for $\sigma$ receptor binding were performed in Tris- $\mathrm{HCl}$ buffers $(50 \mathrm{mM})$ using $1.0 \mathrm{nM}\left[{ }^{3} \mathrm{H}\right](+)$-pentazocine $\left(\sigma_{1}\right), 3.0 \mathrm{nM}$ $\left[{ }^{3} \mathrm{H}\right]$ ditolylguanidine $\left(\left[{ }^{3} \mathrm{H}\right] \mathrm{DTG}\right) / 200 \mathrm{nM}(+)$-pentazocine $\left(\sigma_{2}\right)$, and membranes from whole guinea pig brains as previously described [19]. Non-specific binding was defined by haloperidol $\left(1.0 \mu \mathrm{M} ; \sigma_{1}\right)$ or by DTG $\left(100 \mu \mathrm{M} ; \sigma_{2}\right)$. The IC $_{50}$ values were determined in four to six assays, each performed in duplicate, by non-linear regression of binding data using curve-fitting program Prism 5.0d (Graph-Pad Software, San Diego, CA). $K_{\mathrm{i}}$ values were calculated from $\mathrm{IC}_{50}$ values using the Cheng-Prusoff relationship [20], and input $K_{\mathrm{d}}$ 's of $2.3 \mathrm{nM}$ for $\left[{ }^{3} \mathrm{H}\right](+)$-pentazocine and $23.9 \mathrm{nM}$ for $\left[{ }^{3} \mathrm{H}\right] \mathrm{DTG}[19]$.

\section{Biodistribution studies}

Data for $\left[{ }^{125} \mathrm{I}\right]-1$ and $\left[{ }^{125} \mathrm{I}\right]-2$ were determined using non-fasted, adult male CD1 mice that had been housed on a $12 \mathrm{hr}$ light-dark cycle in temperature and humidity controlled quarters. Each animal received radiotracer $(2.5-3.0 \mu \mathrm{Ci})$ in $0.9 \%$ saline $(0.1 \mathrm{~mL} ; 2 \% \mathrm{EtOH}$ $v / v)$ by tail vein injection. Groups of mice $\left(\mathrm{n}=4,\left[{ }^{125} \mathrm{I}\right]-1 ; \mathrm{n}=5,\left[{ }^{125} \mathrm{I}\right]-\right.$ 2) were euthanized by cervical dislocation at various intervals up to 2 $\mathrm{hr}$, and bloods were obtained by cardiac puncture. Brain, heart, lung, liver, spleen and other organs were harvested and weighed. Tissue radioactivity was measured using an automated gamma counter, and $\% \mathrm{ID} / \mathrm{g}$ wet weight of tissue was calculated in relation to standard dilutions of the ID. Pharmacologic studies of $\left[{ }^{125} \mathrm{I}\right]-1$ and $\left[{ }^{125} \mathrm{I}\right]-2$ followed the same protocol, except haloperidol $(2.5 \mu \mathrm{mol} / \mathrm{kg} ; 0.1 \mathrm{~mL})$ was given by tail vein $5 \mathrm{~min}$ prior to radioligand. Tissue radioactivity was determined for sets $(n=5)$ of drug treated or saline control animals $60 \mathrm{~min}$ after radioligand administration. A two-tailed, unpaired $t$-test at the $95 \%$ confidence level (Prism 5.0d) was employed for statistical analysis.

\section{Results and Discussion}

\section{Chemistry}

The synthetic routes to 1 and 2 , as well as to radioiodinated versions $\left[{ }^{125} \mathrm{I}\right]-1$ and $\left[{ }^{125} \mathrm{I}\right]-2$, are shown in Scheme 1. Alkylation of 4-O-des-methyl SA4503 (3) by (Z)- or (E)-3-(tri- $n$-butylstannyl)prop2-en-1-ol 4-methylbenzenesulfonate was accomplished by treatment with $\mathrm{NaH}$ in DMF at room temperature for 90 min. Work-up and column chromatography provided precursors 4 and 5 in $70 \%$ and $80 \%$ yield, respectively. For the non-radioactive syntheses of 1 and 2, stereo specific iododestannylation was achieved using iodine in methylene

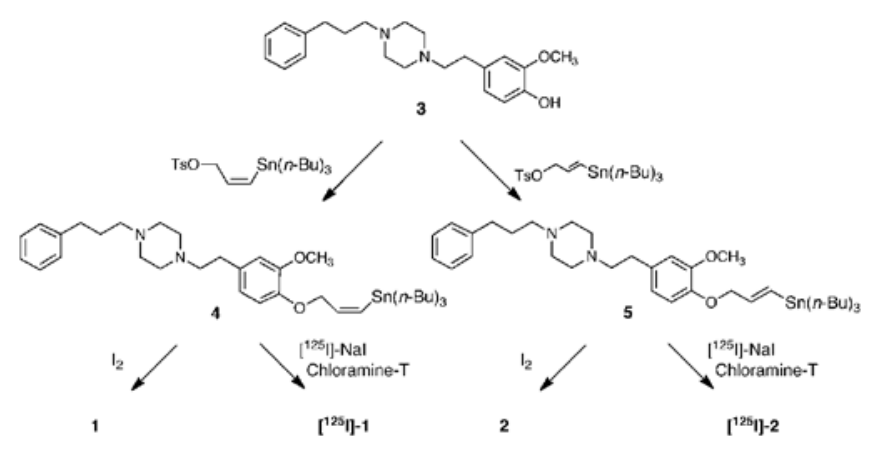

Scheme 1: Synthetic scheme for the preparation of $1 /\left[{ }^{125} \mid\right]-1$ and $2 /\left[{ }^{125} \mid\right]-2$. 
chloride at room temperature for $10 \mathrm{~min}$. Column chromatography gave 1 and 2 in 55\% and 56\% isolated yield, respectively. These target compounds were analytically pure, and gave appropriate combustion analyses and spectroscopic data. The proton NMR data confirmed retention of configuration by the expected vicinal couplings for the $\mathrm{ABX} 2$ spin systems of $(Z)$-isomer $1(3 \mathrm{JAB}=7.9 \mathrm{~Hz})$ and $(E)$-isomer 2 $(3 \mathrm{JAB}=14.6 \mathrm{~Hz})$.

\section{Radiochemistry}

Radiolabeling was performed under mild conditions by

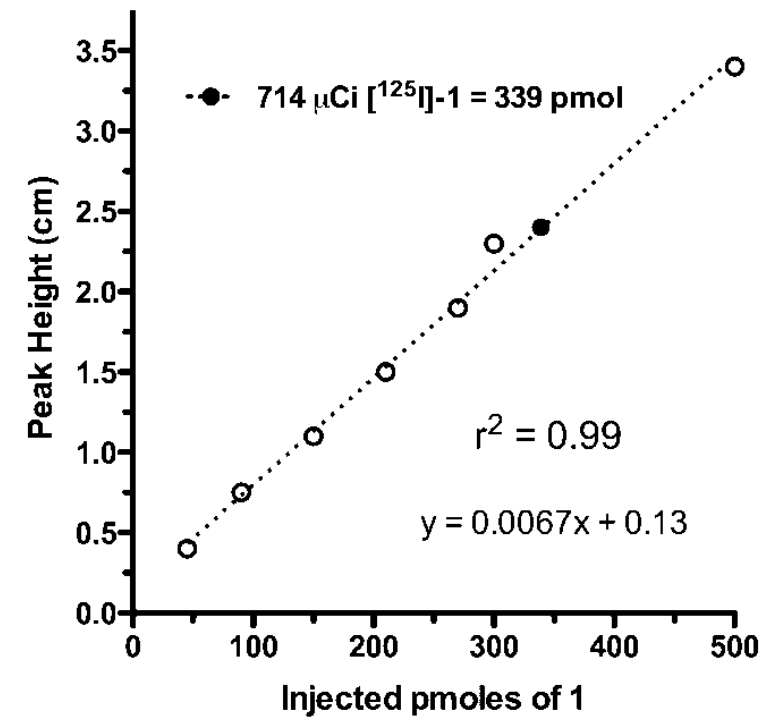

Figure 2: Standard curve constructed from peak heights derived from HPLC injections of increasing mass amounts of 1 (open circles), along with the determination of mass in an aliquot of $\left.{ }^{125}\right]$-1 having known radioactivity (closed circle).

\begin{tabular}{|l|l|l|}
\hline Compound & a $\log \mathbf{D}_{7.4}$ & b $C l o g$ \\
\hline$\left.\left[{ }^{125}\right]\right]-1,1$ & $3.60 \pm 0.13$ & 5.02 \\
\hline$\left.\left[{ }^{125}\right]\right]-2,2$ & $3.62 \pm 0.14$ & 5.02 \\
\hline o-BON & NR & 4.29 \\
\hline m-BON & NR & 4.59 \\
\hline SA4503 & NR & 3.47 \\
\hline
\end{tabular}

a Log $D_{7.4}$ values (means $\pm S D, n=6$ ) were determined by partitioning between $n$-octanol and phosphate buffered saline ( $\mathrm{pH} 7.4)$. ${ }^{\mathrm{b}} \mathrm{ClogP}$ values were calculated using a fragment-based approach by a subroutine of program ChemBioDraw Ultra. $\mathrm{NR}=$ not reported

Table 1: Lipophilicity measures for SA4503 and radioiodinated analogs of SA4503.
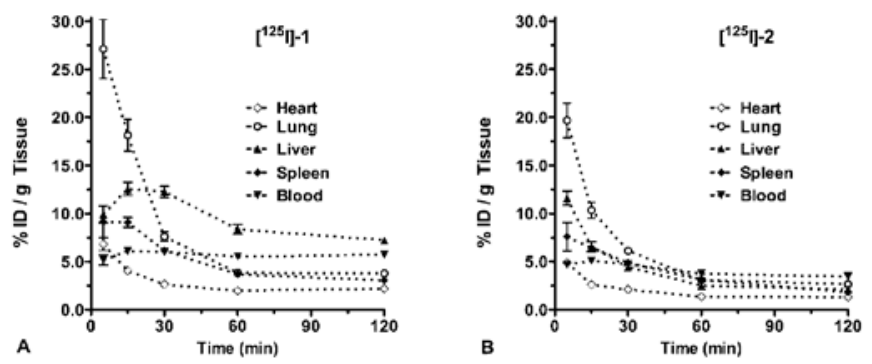

Figure 3: Temporal biodistribution of radioactivity in blood and peripheral organs of male CD1 mice after intravenous administration of [ ${ }^{125}$ I]-1 (Panel $A, n=4)$ and $\left[{ }^{125} \mathrm{I}\right]-2$ (Panel $\left.B, n=5\right)$. Values are \%ID / g (means \pm SEM). Non-visible error bars are contained within the symbol.
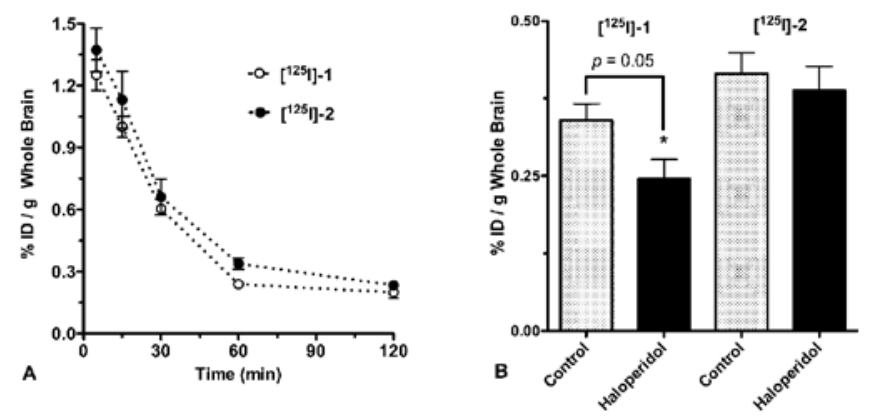

*Significantly reduced compared to saline-treated controls $t$-test).

Figure 4: (Panel A) Temporal biodistribution of radioactivity in whole CD1 mouse brain after intravenous administration of $\left.\left[{ }^{125}\right]\right]-1(n=4)$ and $\left[{ }^{125} \mid\right]-2(n=$ $5)$. Values are \%ID / g (means \pm SEM). Non-visible error bars are contained within the symbol. (Panel B) Effects of pretreatment with intravenous haloperidol $(2.5 \mu \mathrm{mol} / \mathrm{kg})$ on uptake of $\left[{ }^{125}\right]-1$ and $\left[{ }^{125} \mathrm{l}\right]-2$ at $60 \mathrm{~min}$ in whole CD1 mouse brain. Values are \%ID / g (means \pm SEM, $n=5)$.

electrophilic radioiododestannylation of 4 or 5 using no-carrier-added $\left[{ }^{125} \mathrm{I}\right]-\mathrm{NaI}$ and Chloramine- $\mathrm{T}$ at room temperature in methanolic acetic acid for one min. Semi-preparative HPLC purification, followed by solid-phase extraction, gave good isolated radiochemical yields of [ $\left.{ }^{125} \mathrm{I}\right]$ $1(58 \%)$ and $\left[{ }^{125} \mathrm{I}\right]-2$ (57\%). HPLC conditions were used where 1 and 2 were resolved, and retention of configuration upon radioiodination was confirmed. More stringent analytical HPLC studies showed that the purified [ $\left.{ }^{125} \mathrm{I}\right]$-labeled isomers were resolved from each other $\left(\left[{ }^{125} \mathrm{I}\right]-1, t_{\mathrm{R}}=21.2 \mathrm{~min} ;{ }^{125} \mathrm{I}\right]-2, t_{\mathrm{R}}=23.5 \mathrm{~min}$ ), and co-eluted with their non-radioactive counterparts. Specific activities near the theoretical value for iodine-125 $(2175 \mathrm{mCi} / \mu \mathrm{mol})$ were established for $\left[{ }^{125} \mathrm{I}\right]-1$ $(2106 \mathrm{mCi} / \mu \mathrm{mol})$ and $\left[{ }^{125} \mathrm{I}\right]-\mathbf{2}(2097 \mathrm{mCi} / \mu \mathrm{mol})$ by determining the mass associated with an aliquot of purified material having known radioactivity. HPLC methods were used, where mass was related to peak height for 1 and 2 by linear standard curves ranging from 45 to 500 pmol to bracket the region of interest. Figure 2 shows the use of a standard curve to determine that an aliquot of $714 \mu \mathrm{Ci}$ of $\left[{ }^{125} \mathrm{I}\right]-1$ contained 339 pmol 1 by HPLC, leading to the reported $2106 \mathrm{mCi} /$ $\mu \mathrm{mol}$ specific activity.

\section{Lipophilicity}

Log D measurements were made for each radioiodinated compound by partitioning between $n$-octanol and $\mathrm{pH} 7.4$ phosphate buffered saline $\left(\log \mathrm{D}_{7.4}\right)$ using the shake-flask method. Values obtained (Table 1) were essentially identical for $\left[{ }^{125} \mathrm{I}\right]-1\left(\log \mathrm{D}_{7.4} 3.62 \pm 0.14\right)$ and $\left[{ }^{125} \mathrm{I}\right]-2\left(\log \mathrm{D}_{7.4}\right.$ $3.60 \pm 0.13)$. Reversed-phase HPLC, however, could readily distinguish the two isomers through interactions with the stationary phase (vide supra). Computational methods using a fragment-based approach [18] were employed to calculate the lipophilicity (ClogP) of nonradioactive compounds (Table 1 ). Direct $\log \mathrm{D}_{7.4}$ values for [ $\left.{ }^{125} \mathrm{I}\right]-1$ and $\left[{ }^{125} \mathrm{I}\right]-2$ proved $1.42 \log$ units lower than the ClogP values of 5.01. This difference can be attributed to the inability of the computer program to adjust for the protonation status of amines. Since the structures of piperazines SA4503, $o$-BON, $m$-BON, 1 and 2 are so similar (Figure 1 ), it is likely that extrapolated $\log \mathrm{D}_{7.4}$ values for the congeneric series would be near 2.87 for $o$-BON, 3.17 for $m$-BON, and 2.05 for SA4503. In our view, the lower hydrophobicity of $o$-BON compared to $m$-BON is an example of clustered lipophilic compensation, where the effect of the $o$-iodine substituent is moderated by its inclusion within the overall electronic cloud of the phenylpropyl moiety [21]. 


\begin{tabular}{|c|c|c|c|c|c|c|}
\hline \multirow[b]{2}{*}{ Compound } & \multicolumn{3}{|c|}{$\sigma_{1}$ Receptor Binding Parameters } & \multicolumn{3}{|c|}{$\sigma_{2}$ Receptor Binding Parameters } \\
\hline & $I_{50}(n M)$ & $K_{i}(n M)$ & Hill Slope & $\mathrm{IC}_{50}(\mathrm{nM})$ & $K_{i}(\mathrm{nM})$ & Hill Slope \\
\hline 1, (Z)-IA-SA4503 & $15.45 \pm 1.91$ & $10.67 \pm 1.32$ & $1.01 \pm 0.09$ & $18.78 \pm 1.24$ & $16.71 \pm 1.20$ & $1.15 \pm 0.04$ \\
\hline 2, (E)-IA-SA4503 & $24.48 \pm 1.85$ & $16.91 \pm 1.28$ & $1.06 \pm 0.08$ & $20.45 \pm 2.23$ & $18.20 \pm 1.99$ & $0.96 \pm 0.01$ \\
\hline${ }^{\mathrm{a}} \mathrm{O}-\mathrm{BON}$ & $6.4 \pm 0.7$ & NR & NR & $10.2 \pm 1.9$ & NR & NR \\
\hline${ }^{\mathrm{a}} m$-BON & $8.9 \pm 2.8$ & NR & NR & $54.5 \pm 6.6$ & NR & NR \\
\hline bSA4503 & $6.67 \pm 0.30$ & $4.63 \pm 0.21$ & $1.23 \pm 0.06$ & $70.93 \pm 4.86$ & $63.09 \pm 4.33$ & $0.88 \pm 0.05$ \\
\hline
\end{tabular}

Binding parameters for 1 and 2 are means \pm SEM for four to six assays, each performed in duplicate. ${ }^{a} D a t a$ from [15]. ${ }^{b} D a t a$ from [19]. NR = not reported

Table 2: $\sigma$ Receptor binding parameters for SA4503 and iodinated analogs of SA4503.

\section{Sigma receptor binding}

As shown in table 2, substitution of a $(Z)$ - or (E)-iodoallyloxy substituent for the 4-methoxy group of SA4503 was well tolerated. Both stereoisomers displayed moderately high affinities for both $\sigma_{1}$ and $\sigma_{2}$ receptors in guinea pig brain membranes. The $(Z)$-isomer $1\left(K_{\mathrm{i}}=10.67\right.$ $\mathrm{nM})$ showed 1.5-fold higher affinity for $\sigma_{1}$ sites than $(E)$-isomer 2 $\left(K_{\mathrm{i}}=16.91 \mathrm{nM}\right)$, while the $\sigma_{2}$ receptor affinities were nearly equal for both isomers (17-18 nM). Introduction of the bulky iodoallyl group cut $\sigma_{1}$ affinities by 2.5 - to 3.5 -fold with respect to those previously reported for the parent SA4503 [19], while the $\sigma_{2}$ affinities were increased by about 3.5 -fold. Thus, this particular structural modification yielded $\sigma$ ligands 1 and 2 having high affinities, but low subtype selectivity. The affinities of $o$ - and $m$-BON previously reported [15] were close to those of SA4503, and are about 2- to 4 -fold higher for $\sigma_{1}$ sites than we find for $(Z)$ - and (E)-IA-SA4503 (1, 2; Table 2).

\section{Biodistribution studies}

The biodistributions of $\left[{ }^{125} \mathrm{I}\right]-1$ and $\left[{ }^{125} \mathrm{I}\right]-2$ were examined in normal male CD1 mice from 5 to $120 \mathrm{~min}$ after tail vein injection. Temporal distributions of radioactivity for blood and major peripheral organs are shown in Figure 3. High lung uptake followed by rapid clearance, and high liver uptake followed by prolonged retention, were observed for $\left[{ }^{125} \mathrm{I}\right]-1$ (Figure 3A). Lung clearance was fit by a onephase exponential decay $\left(\mathrm{r}^{2}=0.91\right)$, with a half-life of $11.9 \mathrm{~min}$ (data not shown). Interestingly, $\left[{ }^{125} \mathrm{I}\right]-2$ showed high lung uptake and rapid clearance (half-life $9.4 \mathrm{~min}$ ), but relatively modest liver uptake and retention (Figure 3B). Other aspects of the peripheral biodistribution were unremarkable, and consistent with that which would be expected for lipophilic radioligands having no formal charge that clear through the hepatobiliary system.

A primary objective of this work was to determine the potential utility of $\left[{ }^{125} \mathrm{I}\right]-1$ and $\left[{ }^{125} \mathrm{I}\right]-2$ for in vivo studies of cerebral $\sigma$ receptors. Figure $4 \mathrm{~A}$ shows that initial radioligand uptakes in whole brain at $5 \mathrm{~min}$ were $1.37 \pm 0.11 \% \mathrm{ID} / \mathrm{g}$ for $Z$-isomer $\left[{ }^{125} \mathrm{I}\right]-1$ and $1.25 \pm 0.07$ $\% \mathrm{ID} / \mathrm{g}$ for $E$-isomer $\left[{ }^{125} \mathrm{I}\right]-2$. Brain radioactivity levels declined as single exponentials $\left(\mathrm{r}^{2}=0.88-95\right)$ over $120 \mathrm{~min}$, with a similar half-life observed for $\left[{ }^{125} \mathrm{I}\right]-1$ (19.8 $\left.\mathrm{min}\right)$ and $\left[{ }^{125} \mathrm{I}\right]-2(19.2 \mathrm{~min})$. Thus, these radioligands readily cross the blood-brain-barrier. To determine if the radioactive signal could be associated with in vivo binding to $\sigma$ receptors, we examined the effect of pretreatments with haloperidol (Figure 4B). Haloperidol is an antipsychotic that is often used to probe interactions of radioligands with $\sigma$ and other receptors in vivo [22]. Haloperidol (2.5 $\mu \mathrm{mol} / \mathrm{kg}$ ) decreased the brain uptake of $E$-isomer $\left[{ }^{125} \mathrm{I}\right]-2$ at $60 \mathrm{~min}$ by $28 \%(p=0.05)$, but had no effect on the brain uptake of $Z$-isomer [ $\left.{ }^{125} \mathrm{I}\right]-1$. Thus, there appears to be some geometric discrimination between these two stereoisomers in vivo, and the data is consistent with a modest level of specific binding to the cerebral $\sigma_{1}$ receptor for $\left[{ }^{125} \mathrm{I}\right]-2$.

In the periphery, haloperidol inhibited the uptake of $\left.{ }^{[25} \mathrm{I}\right]-$ 2 in liver by $25 \%(p=0.01)$ at $60 \mathrm{~min}$, but not in other organs (data not shown). Haloperidol did not reduce the uptake of $\left[{ }^{125} \mathrm{I}\right]-1$ in the periphery (data not shown). Liver is rich in $\sigma$ receptors [23], but so are a number of other organs $[14,16]$. Taken with the brain data, failure to observe inhibition of $\left[{ }^{125} \mathrm{I}\right]-1$ and $\left[{ }^{125} \mathrm{I}\right]-2$ by haloperidol throughout the periphery indicates limited utility of these radioligands for in vivo studies of $\sigma$ receptors.

The initial uptake of $\left[{ }^{125} \mathrm{I}\right]-1$ and $\left[{ }^{125} \mathrm{I}\right]-2$ at $5 \mathrm{~min}$ in whole mouse brain compares favorably to the results reported by Hirata and colleagues [16] for mouse brain uptake at $5 \mathrm{~min}$ for $\left[{ }^{125} \mathrm{I}\right] \mathrm{o}$-BON $(1.86 \pm 0.36 \% \mathrm{ID} / \mathrm{g})$ and $\left.{ }^{[125} \mathrm{I}\right] m-\mathrm{BON}(1.98 \pm 0.13 \% \mathrm{ID} / \mathrm{g})$. However, haloperidol and other $\sigma$ receptor ligands reduced brain uptake of $\left[{ }^{125} \mathrm{I}\right]$ $o$-BON and $\left[{ }^{125} \mathrm{I}\right] m$-BON by approximately $70 \%$. In addition, $\sigma$ receptor ligands blocked the uptake of $\left[{ }^{125} \mathrm{I}\right] o-\mathrm{BON}$ and $\left[{ }^{125} \mathrm{I}\right] m-\mathrm{BON}$ in liver and several other peripheral organs [16]. These four radioiodinated ligands derived from the SA4503 scaffold have fairly similar $\sigma_{1}$ receptor affinities (Table 2), but $o-\mathrm{BON} / m-\mathrm{BON}$ are 0.43-0.73 log units lower in lipophilicity than $(E)-/(Z)$-IA-SA4503 (Table 1 ). While $\log \mathrm{D}_{74}$ values up to about 4 are tolerated for passage across the blood-brainbarrier, higher lipophilicity usually makes it more difficult to detect the specific binding component of the total binding signal associated with a given receptor-binding radiotracer [24]. A number of other factors, such as degree of metabolic stability, also contribute to the differences observed in vivo between various radiotracers. The low level of specific binding observed in vivo for $\left[{ }^{125} \mathrm{I}\right]-1 /\left[{ }^{125} \mathrm{I}\right]-2$ with respect to $\left[{ }^{125} \mathrm{I}\right]$ $o-\mathrm{BON} /\left[{ }^{125} \mathrm{I}\right] m$-BON seems due, at least in part, to a combination of higher lipophilicities with the lower $\sigma_{1}$ receptor affinities. In this regard, the present studies provided a springboard for the identification of [ $\left.{ }^{125} \mathrm{I}\right]$-labeled $N$-(E-iodoallyl)- $N^{\prime}$-(dimethoxyphenethyl)-piperazine, a metabolically stable radioligand with a $\log \mathrm{D}_{7.4}$ of 2.25 , that exhibits suitable characteristics for binding to the $\sigma_{1}$ receptor in vivo [14].

\section{Conclusions}

$(Z)$ - and (E)-IA-SA4503 were readily synthesized by coupling stannylated alkylating agents to 4-O-des-methyl-SA4503 followed by iododestannylation with retention of configuration. Substitution of $(Z)$ or (E)-iodoallyloxy substituents for the 4-methoxy group of SA4503 proved acceptable by the $\sigma$ receptor pharmacophore. Both stereoisomers displayed moderately high affinities for $\sigma_{1}$ and $\sigma_{2}$ receptors in vitro ( $K_{\mathrm{i}}$ values 11-18 $\left.\mathrm{nM}\right)$. The corresponding radioiodinated ligands also could be prepared in good yields, with high purity and high specific activity. $\log \mathrm{D}_{7.4}$ values for both radioligands were 3.6, which is higher than optimal for receptor-binding radiotracers for in vivo studies. Both radioligands readily cross the blood-brain-barrier of mice, but only the $\left[{ }^{125} \mathrm{I}\right]$-labeled $(E)$-isomer showed a modest degree of specific binding to $\sigma_{1}$ receptors. The studies demonstrate that $\sigma$ receptors have substantial tolerance toward bulky modifications of SA4503 at the 4-position of the dimethoxyphenethyl moiety. This structure activity relationship could aid in the future development of possible therapeutics based on the SA4503 framework.

\section{Acknowledgements}

We thank the National Cancer Institute (P50 CA103130: Center for Single Photon-Emitting Cancer Imaging Agents) and the National Institute on Drug Abuse 
Citation: Xu R, Watkinson LD, Carmack TL, Lever JR, Lever SZ (2012) Synthesis, Sigma Receptor Binding Studies, and In Vivo Evaluation of Radioiodinated (Z)- and (E)-iodoallyl Analogs of SA4503. Med chem 2:131-136. doi:10.4172/2161-0444.1000128

(1RC1DA028477-01; Development of Anti-Cocaine Medications) for partial support of this research. We also acknowledge facilities and resources provided by Harry S. Truman Memorial Veterans' Hospital, and the Life Sciences Mission Enhancement program of the University of Missouri.

\section{References}

1. Matsuno K, Nakazawa M, Okamoto K, Kawashima Y, Mita S (1996) Binding properties of SA4503, a novel and selective sigma 1 receptor agonist. Eur J Pharmacol 306: 271-279.

2. Ruscher K, Shamloo M, Rickhag M, Ladunga I, Soriano L, et al. (2011) The sigma-1 receptor enhances brain plasticity and functional recovery after experimental stroke. Brain 134: 732-746.

3. Rodvelt KR, Lever SZ, Lever JR, Blount LR, Fan KH, et al. (2011) SA4503 attenuates cocaine-induced hyperactivity and enhances methamphetamine substitution for a cocaine discriminative stimulus. Pharmacol Biochem Behav 97: 676-682

4. Rodvelt KR, Oelrichs CE, Blount LR, Fan KH, Lever SZ, et al. (2011) The sigma receptor agonist SA4503 both attenuates and enhances the effects of methamphetamine. Drug Alcohol Depend 116: 203-210.

5. van Waarde A, Buursma AR, Hospers GA, Kawamura K, Kobayashi T, et al. (2004) Tumor imaging with 2 sigma-receptor ligands, 18F-FE-SA5845 and 11C-SA4503: a feasibility study. J Nucl Med 45: 1939-1945.

6. Sakata M, Kimura Y, Naganawa M, Oda K, Ishii K, et al. (2007) Mapping of human cerebral sigma, receptors using positron emission tomography and $\left[{ }^{11} \mathrm{C}\right]$ SA4503. Neuroimage 35: 1-8.

7. Ishikawa M, Sakata M, Ishii K, Kimura Y, Oda K, et al. (2009) High occupancy of $\sigma_{1}$ receptors in human brain after single oral administration of donepezil: A positron emission tomography study using $\left[{ }^{11} \mathrm{C}\right] \mathrm{SA} 4503$. Int $\mathrm{J}$ Neuropsychopharmacol 12: 1127-1131.

8. Kawamura K, Elsinga PH, Kobayashi T, Ishii S, Wang WF, et al. (2003) Synthesis and evaluation of ${ }^{11} \mathrm{C}$ - and ${ }^{18} \mathrm{~F}$-labeled 1-[2-(4-alkoxy-3-methoxyphenyl)ethyl]-4(3-phenylpropyl) piperazines as sigma receptor ligands for positron emission tomography studies. Nucl Med Biol 30: 273-284.

9. Elsinga PH, Tsukada H, Harada N, Kakiuchi T, Kawamura K, et al. (2004) Evaluation of $\left[{ }^{18} \mathrm{~F}\right]$ fluorinated sigma receptor ligands in the conscious monkey brain. Synapse 52: 29-37

10. Xu R, Lever JR, Lever SZ (2007) Synthesis and in vitro evaluation of tetrahydroisoquinolinyl benzamides as ligands for sigma receptors. Bioorg Med Chem Lett 17: 2594 - 2597.

11. Nahas RI, Lever JR, Lever SZ (2008) Synthesis and structure-activity relationships of $N$-(3-phenylpropyl)- $N$ '-benzylpiperazines: potent ligands for $\sigma_{1}$ and $\sigma_{2}$ receptors. Bioorg Med Chem 16: 755-761.
12. Fitzsimmons JM, Lever JR, Lever SZ (2011) Synthesis and $\sigma_{1}$ receptor binding of halogenated $N, N^{\prime}$-diphenethylethylenediamines. Medchem 1: 102.

13. Fan KH, Lever JR, Lever SZ (2011) Effect of structural modification in the amine portion of substituted aminobutyl-benzamides as ligands for binding $\sigma_{1}$ and $\sigma_{2}$ receptors. Bioorg Med Chem 19: 1852-1859.

14. Lever SZ, Xu R, Fan KH, Fergason-Cantrell EA, Carmack TL, et al. (2012) Synthesis, radioiododination and in vitro and in vivo sigma receptor studies of $N$-1-allyl- $N^{\prime}$-4-phenethylpiperazine analogs. Nucl Med Biol 39: 401 - 414.

15. Hirata M, Mori T, Soga S, Umeda T, Ohmomo Y (2006) Synthesis and in vitro evaluation of iodinated derivatives of piperazine as a new ligand for sigma receptor imaging by single photon emission computed tomography. Chem Pharm Bull 54: 470-475.

16. Hirata M, Mori T, Soga S, Umeda T, Ohmomo $Y(2006)$ In vivo evaluation of radioiodinated 1-[2-(3,4-dimethoxylphenyl)ethyl]-4-(3-phenylpropyl)-piperazine derivatives as new ligands for sigma receptor imaging using single photon emission computed tomography. Biol Pharm Bull 29: 2009-2015.

17. Musachio JL, Lever JR (1992) Vinylstannylated alkylating agents as prosthetic groups for radioiodination of small molecules: design, synthesis, and application to iodoallyl analogues of spiperone and diprenorphine. Bioconjug Chem 3: 167175.

18. Leo AJ (1993) Calculating log Poct from structures. Chem Rev 93: 1281-1306

19. Lever JR, Gustafson JL, Xu R, Allmon RL, Lever SZ (2006) $\sigma_{1}$ and $\sigma_{2}$ receptor binding affinity and selectivity of SA4503 and fluoroethyl SA4503. Synapse 59 : 350-358.

20. Cheng Y, Prusoff WH (1973) Relationship between the inhibition constant (K1) and the concentration of inhibitor which causes 50 per cent inhibition (I50) of an enzymatic reaction. Biochem Pharmacol 22: 3099-3108.

21. Coenen HH, Mertens J, Mazière B (2006) Radioionidation reactions for pharmaceuticals: Compendium for effective synthesis strategies. Springer, Dordrecht, The Netherlands.

22. Collier TL, Waterhouse RN, Kassiou M (2007) Imaging sigma receptors applications in drug development. Curr Pharm Des 13: 51-72.

23. Hellewell SB, Bruce A, Feinstein G, Orringer J, Williams W, et al. (1994) Rat liver and kidney contain high densities of sigma 1 and sigma 2 receptors: characterization by ligand binding and photoaffinity labeling. Eur $\mathrm{J}$ Pharmacol 268: 9-18.

24. Waterhouse RN (2003) Determination of lipophilicity and its use as a predictor of blood-brain barrier penetration of molecular imaging agents. Mol Imaging Biol 5: 376-389. 